\title{
PENGEMBANGAN MEDIA PEMBELAJARAN BERBENTUK ANIMASI BERBASIS MOBILE LEARNING (M-LEARNING) PADA MATERI GERAK LURUS DI SMP
}

\author{
Anas Pranila Paramita ${ }^{1, a)}$, Betty Zelda Siahaan, I Made Astra \\ ${ }^{1}$ Program Pasca Sarjana Pendidikan Fisika, Fakultas Matematika Dan Ilmu Pengetahuan Alam \\ Universitas Negeri Jakarta, Jl. Pemuda No. 10, Jakarta 13220 Indonesia \\ Email: a)paramita.saintpaul@gmail.com
}

\begin{abstract}
Abstrak
Penelitian ini bertujuan untuk mengembangkan media pembelajaran animasi berbasis mobile learning untuk meningkatkan belajar mandiri siswa pada materi gerak lurus di SMP. Dalam melakukan penelitian digunakan metode Research and Development yang mengacu pada model ADDIE. Tahapan dalam pengembangan penelitian ini, yaitu Analyze, Design, Development, Implementasi, dan Evaluation. Media didesain dan dikembangkan dengan menggunakan aplikasi Adobe Flash Professional CS6. Berdasarkan hasil analisis kebutuhan media pembelajaran didapatkan bahwa sebanyak $30 \%$ saja guru menggunakan bantuan media visual animasi dan belum ada guru menerapkan mobile learning dalam pembelajaran, maka pengembangan media pembelajaran animasi berbasis mobile learning pada materi gerak lurus dapat dijadikan sebagai bahan ajar pendukung siswa. Media pembelajaran ini memuat materi, animasi dan simulasi, latihan soal dan kuis. Media yang dikembangkan telah divalidasi oleh ahli media menggunakan instrumen berupa angket. Serta layak dijadikan sebagai media pembelajaran di SMP.
\end{abstract}

Kata-kata kunci: media pembelajaran, mobile learning, animasi, gerak lurus, ADDIE.

\begin{abstract}
This research aims to develop the learning of animation media base of mobile learning to improve student self-learning on the material straight motion at Junior High School. This study used research and development method which refers to mode of ADDIE. The stages of the research are, analysis, design, development, implementation, and evaluation. The media is designed and developed by using Adobe Flash Professional CS6. Based on the result of learning media requirement analysis found that as much as 30\% of teachers useanimation visual media and no teachers implement mobile. Learning into the learning, then the development of mobile learning on the material straigh of movement can be support the students as teaching of material to learn independetly. The media has been validated by media experts using quisionaire instruments.
\end{abstract}

Keywords: instructional media, mobile learning, animation, ADDIE models. 


\section{PENDAHULUAN}

Dengan berkembangnya teknologi informatika, maka disangkutkan dengan pendidikan untuk memajukan pendidikan khususnya di Indonesia. Salah satunya yaitu penggunaan ICT dapat mendukung pembelajaran konvensioal bahkan telah mengubah sistem pembelajaran tradisional menjadi pola modern.

Semakin banyak yang memiliki dan menggunakan Gadged, maka membuka peluang penggunaan perangkat teknologi bergerak dalam dunia pendidikan. Penggunaan perangkat bergerak (mobile device) dalam proses pembelajaran kemudian dikenal sebagai mobile learning. Mobile learning adalah pembelajaran dimana pembelajar dapat mengakses materi pembelajaran, arahan dan aplikasi yang berkaitan dengan pembelajaran, dimanapun, dan kapanpun [1].

Kehadiran mobile learning ini ditujukan sebagai pelengkap pembelajaran yang ada serta memberikan kesempatan pada siswa untuk mempelajari kembali materi yang kurang dikuasai dan dapat menumbuhkan gairah belajar sehingga memungkinkan siswa belajar secara mandiri sesuai dengan bakat dan kemampuan visualnya [2].

Berdasarkan pernyataan di atas, peneliti memandang perlu untuk dikembangkannya suatu media pembelajaran berbentuk animasi berbasis mobile learning pada materi gerak di SMP.

\section{METODOLOGI PENELITIAN}

Penelitian ini merupakan penelitian dan pengembangan (research and development) yang mengacu pada model ADDIE. Produk yang dikembangkan dalam penelitian ini adalah animasi berbasis mobile learning (m-learning) untuk meningkatkan belajar mandiri pada materi gerak lurus di SMP. Model tersebut memiliki lima tahap yaitu Analysis, Design, Development, Implementasi, dan Evaluation [3].

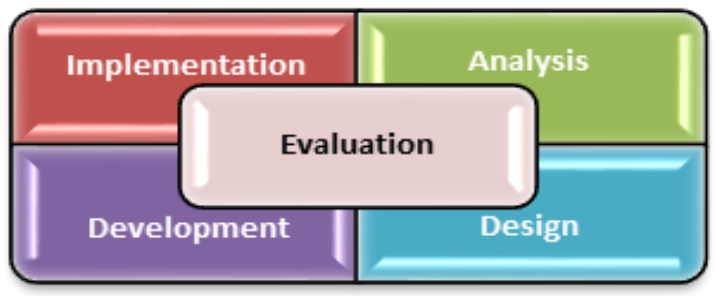

Gambar 1. Tahap Pengembangan Model ADDIE

Pada tahap Analysis melakukan proses analisis kebutuhan yang dikenal sebagai Training Need Analysis. Berdasarkan hasil analisis kebutuhan media pembelajaran pada materi Gerak lurus kelas 7 di SMP yang dilakukan dengan menyebarkan angket oleh 12 siswa dan 11 guru Fisika yang tersebar di Jakarta, bahwa didapatkan $80 \%$ guru mengajar dengan menggunakan powerpoint dan $60 \%$ guru mengajar dengan bantuan papan tulis, $30 \%$ dengan menyisipkan simulasi dan animasi dan $50 \%$ guru menggunakan bantuan laptop dalam mengajar tetapi $0 \%$ guru menggunakan smartphone, artinya pengembangan media pembelajaran berbentuk mobile learning belum ada yang mencoba menerapkan, oleh responden. Disamping itu pada analisis kebutuhan siswa didapat bahwa 83,3\% siswa tidak menguasai apa yang telah diajarkan guru, padahal 58,3\% menyatakan metode yang guru ajarkan menyenangkan. Tetapi ada $66,6 \%$ siswa merasa bosan dengan media yang digunakan guru dalam pembelajaran dan sebanyak $58,3 \%$ siswa menginginkan pembelajaran fisika dengan menggunakan Gadged yang mereka punya yang bisa diakses di manapun berada sehingga ada 83,3\% siswa menginginkan suatu inovasi pembelajaran yang bisa diakses di mana saja bisa dipelajari secara mandiri dan $100 \%$ siswa mendukung jika dibuat pembelajaran berbentuk animasi dengan sistem android.

Design dan Development merupakan tahap kedua dan ketiga. Pada tahap ini pengembang membuat storyboard, membuat alur pengembangan, pengumpulan bahan pendukung, membuat desain, memproduksi, dan menampilkan bahan terkait untuk melengkapi produk. 
Selanjutnya rancangan produk direalisasikan, yaitu membuat animasi berbasis mobile learning sebagai media pembelajaran untuk meningkatkan belajar mandiri siswa yang dikembangkan berdasarkan pada penelitian pendahuluan dan perencanaan.

Pada tahap selanjutnya yaitu implementation, di tahap ini produk telah divalidasi oleh ahli media, ahli pembelajaran, dan ahli materi diujicobakan kepada peserta didik. Uji coba dilakukan pada skala kecil dan skala besar. Sekala kecil dilakukan pada peserta didik kelas VIII dan IX SMPK Santo Paulus, sedangkan skala besar dilakukan pada peserta didik kelas VII SMPK Santo Paulus Jakarta.

Pada tahap kelima yaitu Evaluation. Di tahap ini media mobile learning yang telah diimplementasikan kepada peserta didik mendapatkan komentar dan saran baik dari peserta didik dan juga dari pendidik. Selanjutnya dilakukan revisi kembali hingga menjadi produk yang layak dan lebih baik.

Teknik analisis data dari angket uji validitas dinilai menggunakan penilaian skala Likert dengan nilai 1 sampai 4 sebagai berikut [4]:

Tabel 1. Skala Likert untuk Penilaian

\begin{tabular}{clc}
\hline No. & Alternatif Jawaban & Bobot Skor \\
\hline 1 & Sangat Baik & 4 \\
2 & Baik & 3 \\
3 & Kurang & 2 \\
4 & Sangat Kurang & 1 \\
\hline
\end{tabular}

Selanjutnya hasil penelitian validasi dihitung dengan cara sebagai berikut:

$$
\text { Presentase skor }=\frac{\Sigma \text { skor perolehan }}{\Sigma \text { skor maksimum }} \times 100 \%
$$

Presentase skor yang diperoleh selanjutnya diukur dengan menggunakan intrepretasi skor untuk skala Likert, yaitu sebagai berikut:

Tabel 2. Interpretasi Skala Likert

\begin{tabular}{clc}
\hline No. & Interpretasi & Presentase \\
\hline 1 & Sangat Kurang & $0 \%-25 \%$ \\
2 & Kurang & $26 \%-50 \%$ \\
3 & Baik & $51 \%-75 \%$ \\
4 & Sangat Baik & $76 \%-100 \%$ \\
\hline
\end{tabular}

\section{HASIL DAN PEMBAHASAN}

Produk hasil pengembangan adalah aplikasi yang memuat animasi berbasis mobile learning pada materi gerak lurus di SMP. Aplikasi ini adalah aplikasi tertutup karena untuk masuk ke dalam aplikasi pengguna harus register lebih dahulu kemudian login email dan pasword. Aplikasi ini bisa diakses secara online dan ofline. Perangkat ofline ketika mengakses media pembelajaran, sedangkan aplikasi harus online ketika melaksanakan kuis di akhir pembelajaran yang kemudian dihubungkan ke server untuk melihat nilai secara langsung. Nilai bisa terlihat oleh admin maupun user.

Aplikasi ini dilengkapi adminitrator yaitu pendidik yang berperan untuk memonitor siapa saja yang mengakses aplikasi ini, melihat hasil kuis, menambah materi. Selanjutnya adanya peserta didik yang berperan mengakses materi.

Selain itu, pada aplikasi ini dibuat semenarik mungkin dengan animasi-animasi yang dilengkapi dengan menu register, login, home, back, exit dan cara penggunaan secara singkat.

Berikut ini adalah tampilan dari media pembelajaran animasi berbasis mobile learning yang telah dikembangkan: 


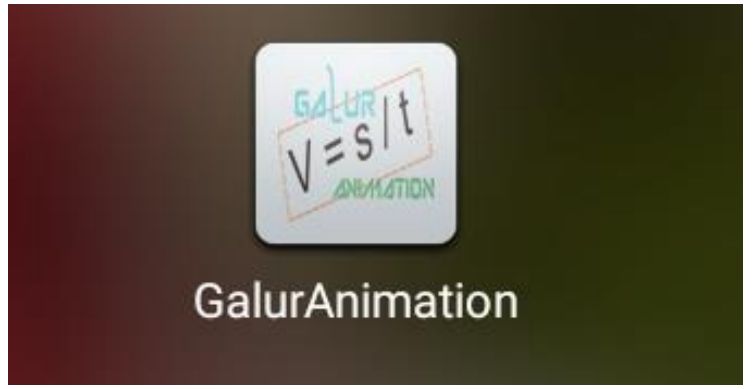

Gambar 2. Tampilan icon pada aplikasi

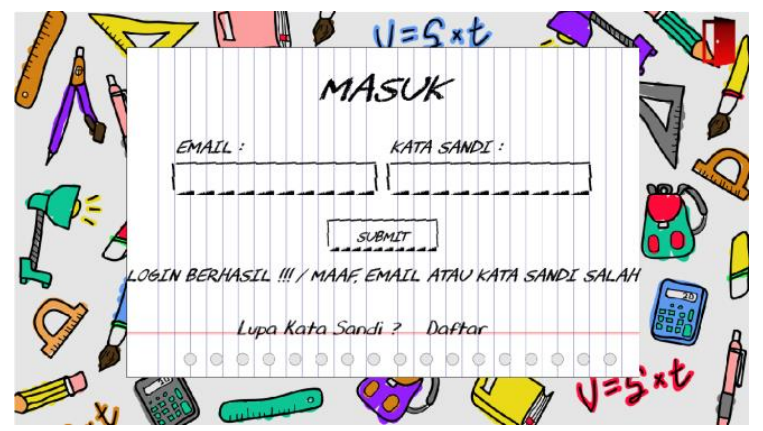

Gambar 3. Tampilan awal untuk administrator login

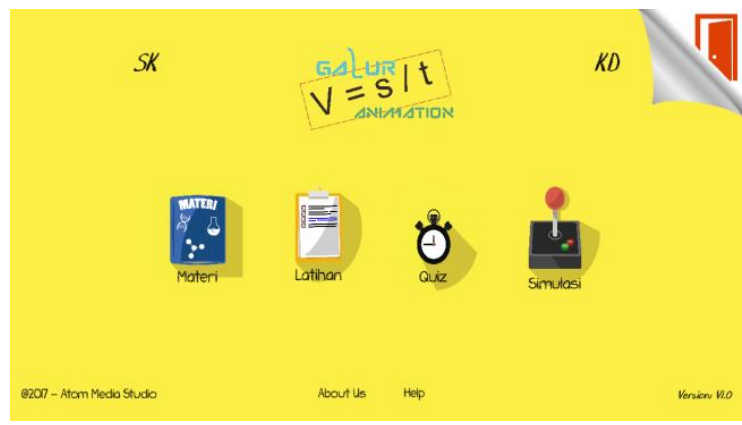

Gambar 4. Tampilan main menu

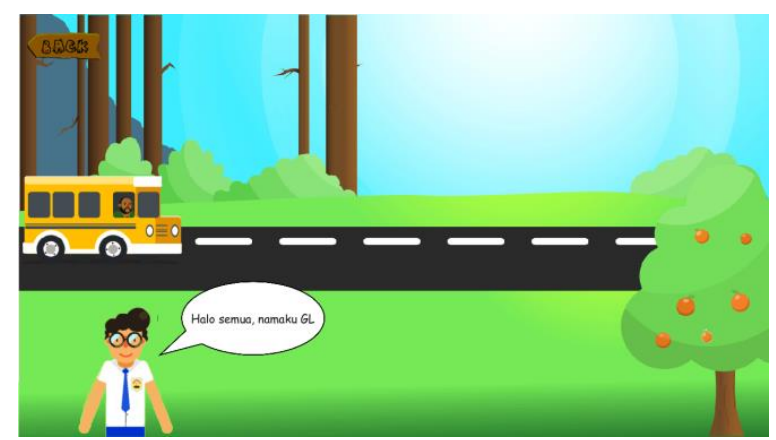

Gambar 5. Tampilan animasi awal 


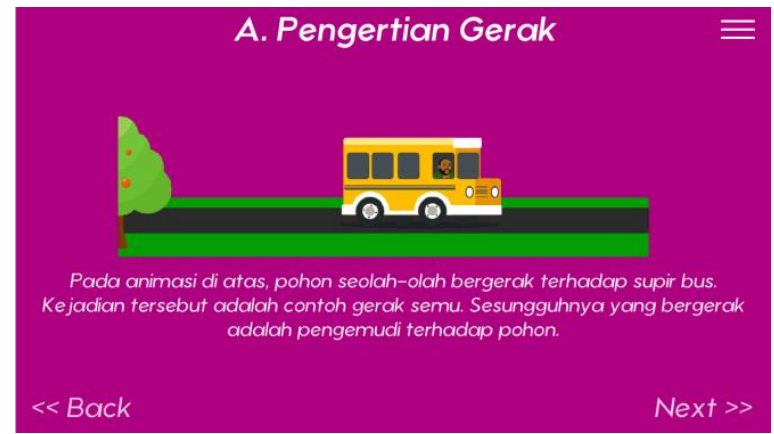

Gambar 6. Tampilan materi

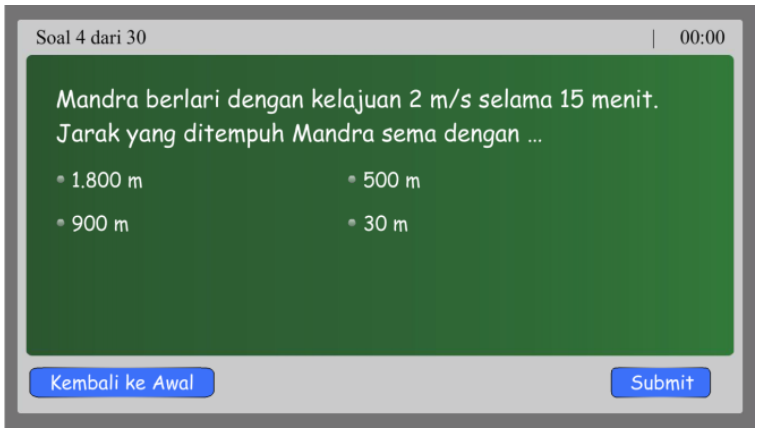

Gambar 7. Tampilan kuis

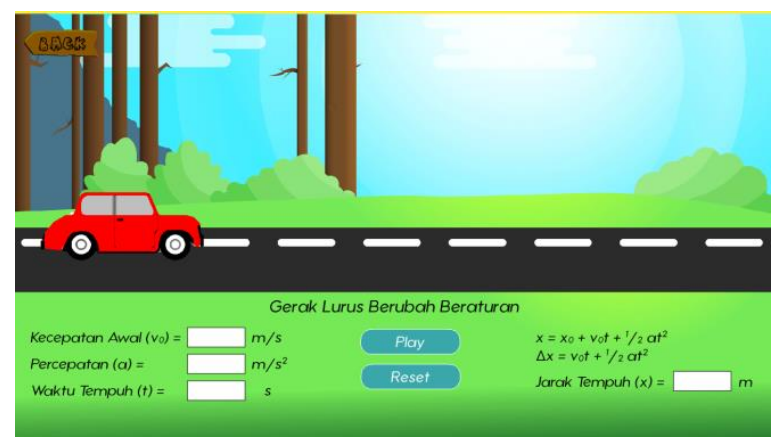

Gambar 8. Tampilan animasi

Berdasarkan hasil uji validasi media dan validasi materi oleh para ahli, didapatkan hasil sebagai berikut:

Tabel 3. Hasil uji validasi

\begin{tabular}{ccc}
\hline Uji Validasi & Presentase & Interpretasi \\
\hline Ahli media & $91 \%$ & Sangat baik \\
Ahli materi & $89 \%$ & Sangat baik \\
\hline
\end{tabular}

Media pembelajaran animasi berbasis mobile learning yang sudah layak digunakan kemudian diujicobakan pada kelompok sekala kecil berjumlah 10 siswa kelas IX yang sudah pernah menempuh pembelajaran gerak lurus. Tahap ini dilakukan agara dapat mengetahui media yang sudah dikembangkan efektif digunakan sebagai pembelajaran mandiri. Kemudian setelah itu, dilakukan ujicoba kelompok skala besar dengan 54 siswa kelas VII SMPK Santo Paulus.

Uji perbedaan (N-gain) yang dilakukan terhadap nilai pre test dan post test didapatkan bahwa terdapat peningkatan nilai hasil belajar mandiri. Hasil nilai test awal dan test akhir pada kelas eksperimen adalah sebagai berikut: 
Tabel 4. N-Gain hasil belajar mandiri

\begin{tabular}{llc}
\hline Tipe Test & Pre test & Post test \\
\hline Rata-rata & 42 & 77,11 \\
N-gain & & 0,6054 \\
\hline
\end{tabular}

Peningkatan nilai peserta didik dilihat dengan membandingkan nilai sebelum menggunakan media pembelajaran animasi berbasis mobile learning dan nilai sesudah menggunakan media pembelajaran animasi berbasis mobile learning, nilai hasil belajar mandiri pada siswa adalah sebagai berikut:

Tabel 5. Kenaikan Nilai Hasil Belajar Mandiri

\begin{tabular}{lll}
\hline Tipe Test & Pre test & Post test \\
\hline Rata-rata & 42 & 77,11 \\
Persentase kenaikan $(\%)$ & $35 \%$ & \\
\hline
\end{tabular}

Terdapat rata-rata kenaikan nilai hasil belajar mandiri sebelum dan sesudah menggunakan media pembelajaran animasi berbasis mobile learning sebesar 35\%. Dapat dilihat bahwa berdasarkan data tersebut dapat disimpulkan bahwa media pembelajaran animasi berbasis mobile learning dapat meningkatkan hasil belajar siswa dengan didukung oleh hasil angket sebelum dan sesudah belajar, seperti dibawah ini:

Tabel 6. Kenaikan prosentase belajar mandiri siswa

\begin{tabular}{lll}
\hline Tipe Test & Pre test & Post test \\
\hline Rata-rata & $56 \%$ & $70 \%$ \\
Persentase kenaikan $(\%)$ & $14 \%$ & \\
\hline
\end{tabular}

Dengan menyebar angket belajar mandiri, maka rata-rata peningkatan persentase siswa belajar mandiri sebelum dan sesudah menggunakan media pembelajaran animasi berbasis mobile learning sebesar $14 \%$.

\section{SIMPULAN}

Berdasarkan hasil pembahasan diatas dapat disimpulkan bahwa media pembelajaran animasi berbasis mobile learning sudah dikembangan sesuai model dan layak digunakan dalam pembelajaran.

\section{UCAPAN TERIMAKASIH}

Terakhir, penulis mengucapkan terimakasih kepada Ibu Dr. Betty Zelda Siahaan, MM dan Bapak Prof. Dr. I Made Astra, M.Si. yang telah banyak memberikan ilmu dan bimbingan kepada penulis. Terlebih juga Penulis mengucapkan terimakasih kepada Yayasan Suaka Insan Suster - Suster SPC yang telah memberikan dukungan moril dan materiil serta pihak-pihak yang membantu dari proses awal pembuatan dan penelitian ini selesai.

\section{REFERENSI}

[1] Husamah. 2014. Pembelajaran Bauran (Blended Learning). Jakarta: Prestasi Pustakaraya.

[2] Riyana. 2009. Media Pembelajaran: Pengembangan, Pemanfaatan, dan penilaian. Bandung: CV Wacana Prima.

[3] Sugiyono. 2016. Metode Penelitian Dan Pengembangan (Research and Development). Bandung: Alfabeta.

[4] Arikunto, S. 2009. Dasar-Dasar Evaluasi Pndidikan. Jakarta: Bumi Aksara. 